\title{
Classical scrapie prions in ovine blood are associated with B lymphocytes and platelet-rich plasma
}

\author{
Rohana P Dassanayake ${ }^{1 *}$, David A Schneider ${ }^{2}$, Thomas C Truscott ${ }^{2}$, Alan J Young ${ }^{3}$, Dongyue Zhuang ${ }^{2}$ and \\ Katherine I O'Rourke ${ }^{1,2}$
}

\begin{abstract}
Background: Classical scrapie is a naturally occurring transmissible spongiform encephalopathy of sheep and goats characterized by cellular accumulation of abnormal isoforms of prion protein $\left(\mathrm{PrP}^{\mathrm{Sc}}\right)$ in the central nervous system and the follicles of peripheral lymphoid tissues. Previous studies have shown that the whole blood and buffy coat blood fraction of scrapie infected sheep harbor prion infectivity. Although PrPSc has been detected in peripheral blood mononuclear cells (PBMCs), plasma, and more recently within a subpopulation of B lymphocytes, the infectivity status of these cells and plasma in sheep remains unknown. Therefore, the objective of this study was to determine whether circulating PBMCs, B lymphocytes and platelets from classical scrapie infected sheep harbor prion infectivity using a sheep bioassay.

Results: Serial rectal mucosal biopsy and immunohistochemistry were used to detect preclinical infection in lambs transfused with whole blood or blood cell fractions from preclinical or clinical scrapie infected sheep. Prpsc immunolabeling was detected in antemortem rectal and postmortem lymphoid tissues from recipient lambs receiving PBMCs (15/15), CD72+ B lymphocytes (3/3), CD21+ B lymphocytes (3/3) or platelet-rich plasma (2/3) fractions. As expected, whole blood (11/13) and buffy coat (5/5) recipients showed positive PrPS labeling in lymphoid follicles. However, at 549 days post-transfusion, $\mathrm{PrP}^{\mathrm{SC}}$ was not detected in rectal or other lymphoid tissues in three sheep receiving platelet-poor plasma fraction.

Conclusions: Prion infectivity was detected in circulating PBMCs, $\mathrm{CD} 72^{+}$pan B lymphocytes, the $\mathrm{CD} 21^{+}$ subpopulation of B lymphocytes and platelet-rich plasma of classical scrapie infected sheep using a sheep bioassay. Combining platelets with B lymphocytes might enhance $\mathrm{Pr}^{\mathrm{Sc}}$ detection levels in blood samples.
\end{abstract}

\section{Background}

Prion diseases or transmissible spongiform encephalopathies (TSEs) are unique, fatal neurodegenerative disorders that affect a variety of species including sheep and goats (scrapie), cattle (bovine spongiform encephalopathy, BSE), human (Creutzfeldt-Jakob disease, CJD), mink (transmissible mink encephalopathy, TME), deer, elk and moose (chronic wasting disease, CWD). A characteristic feature of TSEs is the accumulation of an alternative conformational isoform $\left(\mathrm{PrP}^{\mathrm{Sc}}\right)$ of the host-encoded normal prion protein $\left(\operatorname{PrP}^{\mathrm{c}}\right)$ in the central nervous system $[1,2]$.

\footnotetext{
* Correspondence: rohana1@vetmed.wsu.edu

'Department of Veterinary Microbiology and Pathology, College of Veterinary Medicine, Washington State University, Pullman, WA $99164-7040$ USA

Full list of author information is available at the end of the article
}

In classical ovine scrapie, deposition of $\mathrm{PrP}^{\mathrm{Sc}}$ in the lymphoreticular system precedes accumulation in the central nervous system [3]. $\operatorname{PrP}^{\mathrm{Sc}}$ is readily detected in this preclinical stage by biopsy of the lymphoid tissue in the nictitating membrane $[4,5]$ or in the rectoanal mucosaassociated lymphoid tissue (RAMALT; [6,7]).

The early and persistent presence of $\mathrm{PrP}^{\mathrm{Sc}}$ in the lymph nodes in classical ovine scrapie, human variant CJD (vCJD), CWD and most rodent scrapie models suggests that prions are disseminated in the peripheral blood and/ or lymphatics and that peripheral blood might be a suitable target for preclinical diagnostic testing. Prion infectivity in ovine blood was confirmed by transfusions of whole blood, buffy coat, red cell concentrates, plasma or platelets from donor sheep with experimental BSE or classical

\section{Biomed Central}


scrapie [8-11]. $\operatorname{PrP}^{\mathrm{Sc}}$ was detected in PBMCs of 10 of 10 clinical scrapie infected sheep using protein misfolding cyclic amplification (PMCA) [12] but in only 44 of 80 clinical scrapie infected sheep when using a conventional enzyme linked immunosorbent assay (ELISA) [13]. A recent ELISA-based study concluded that $\operatorname{PrP}^{\mathrm{Sc}}$ was principally associated with a subpopulation of B lymphocytes in scrapie infected sheep [14]. Although $\operatorname{PrP}^{\mathrm{Sc}}$ was detected in B lymphocytes in 11 of 11 clinical scrapie infected sheep, B lymphocytes from only three of five scrapie infected sheep at the preclinical stage were positive for $\mathrm{PrP}^{\mathrm{Sc}}$ by ELISA. PrP $\mathrm{P}^{\mathrm{Sc}}$ has also been detected in plasma samples collected from both preclinical and clinical scrapie infected sheep but only after combining a novel surround optical fiber immunoassay (SOFIA) with limited $\operatorname{PrP}^{\mathrm{Sc}}$ amplification by PMCA [15].

Although $\mathrm{PrP}^{\mathrm{Sc}}$ has been detected in the blood of scrapie-infected sheep by enriching conventional ELISA-based assay with cellular fractions including PBMCs or B lymphocytes, the frequency of such detection was lower during the preclinical stage of the disease. Thus, the objectives of this study were to identify blood fractions of sheep which harbor relatively high levels of prion infectivity, including during the preclinical stage of disease. The present study used a short-observation transfusion model in the natural host to determine if relatively high infectivity was present in the total PBMC population, a CD72 $2^{+}$ pan B lymphocyte population, a CD $21^{+}$subpopulation of B lymphocytes and either platelet-rich or platelet-poor plasma isolated from the blood of classical scrapie-infected sheep. In addition, it was also determined if high infectivity could be demonstrated in both platelet-rich and plateletpoor plasma during clinical disease. Such demonstrations should help guide further efforts toward improvement of ELISA-based scrapie detection sensitivity by pre-assay enrichment with relevant blood fractions.

\section{Results}

\section{Scrapie infectivity associates with blood components} (i) Whole blood transfused recipients develop preclinical scrapie

Whole blood was collected from three preclinical and three clinical scrapie infected donor sheep and different blood volumes were transfused to 13 recipients as shown in Table 1. Three of four PRNP MARQ/MVRQ recipients and all four MARQ/MARQ recipients became antemortem RAMALT positive for $\operatorname{PrP}^{\mathrm{Sc}}$ between 123 to 235 days post transfusion (dpt) and 222 to $252 \mathrm{dpt}$, respectively (Table 1). None of these eight animals showed any signs of scrapie when they were euthanized at 236 to 267 dpt. IHC analysis of postmortem rectal and retropharyngeal lymph nodes of all eight animals showed positive $\mathrm{PrP}^{\mathrm{Sc}}$ labeling in lymphoid follicles (Table 2 Figure 1A). $\mathrm{PrP}^{\mathrm{Sc}}$ was undetectable in antemortem and postmortem rectal tissues and other lymphoid tissues of two MARQ/ TARQ recipients (Tables 1 and 2 ). $\mathrm{PrP}^{\mathrm{Sc}}$ labeling was also not detected in antemortem rectal biopsies of all three TARQ/MVRQ animals; however when necropsied rectal tissues of two animals and retropharyngeal lymph nodes of all three animals showed positive labeling for $\mathrm{PrP}^{\mathrm{Sc}}$ (Table 2). Clinical signs were not observed in any of these three recipients and $\mathrm{PrP}^{\mathrm{Sc}}$ was undetectable in brain tissues of all the animals.

\section{(ii) Buffy coat transfused recipients develop preclinical scrapie}

Buffy coat fraction was prepared from one clinical scrapie infected donor sheep and transfused to five recipients (Table 1). All three MARQ/MARQ buffy coat recipients became antemortem RAMALT biopsy positive for $\mathrm{PrP}^{\mathrm{Sc}}$ between 239 to $549 \mathrm{dpt}$ (Table 1 Figure 1B). Postmortem rectal tissues and retropharyngeal lymph nodes along with other lymphoid tissues of these three animals showed positive $\mathrm{PrP}^{\mathrm{Sc}}$ labeling in lymphoid follicles (Table 2) although $\operatorname{PrP}^{\mathrm{Sc}}$ was not detected in the brain tissues. Two of these three animals did not show clinical signs of scrapie when they were euthanized at 275 and $306 \mathrm{dpt}$. Clinical signs of scrapie developed in the remaining animal, which was euthanized at $1259 \mathrm{dpt}$. Brain tissue of this animal (ID 3832) was positive for $\mathrm{PrP}^{\mathrm{Sc}}$ by both $\mathrm{IHC}$ and WB assays. One of two remaining buffy coat recipients with the MARQ/TARQ PRNP genotype became rectal biopsy positive for $\mathrm{PrP}^{\mathrm{Sc}}$ labeling in lymphoid follicles at $757 \mathrm{dpt}$ while $\mathrm{PrP}^{\mathrm{Sc}}$ labeling was not detected from the remaining other animal at $1095 \mathrm{dpt}$. There were no clinical signs of scrapie in either of these two animals when euthanized at $1391 \mathrm{dpt}$ (Table 1). Postmortem rectal tissues and retropharyngeal lymph nodes along with other lymphoid tissues of the RAMALT positive animal (ID 3819) showed positive $\operatorname{PrP}^{\mathrm{Sc}}$ labeling in lymphoid follicles and the brain tissues by IHC (Table 2). Lymphoid follicles of retropharyngeal lymph nodes and ileocecal junction of the other animals (ID 3825) showed positive $\operatorname{PrP}^{\mathrm{Sc}}$ labeling (Table 2).

(iii) Peripheral blood mononuclear cell transfused recipients develop preclinical scrapie

PBMCs were prepared from five preclinical scrapie infected donor sheep and transfused to 15 recipients (Table 1). Antemortem rectal biopsies from four of five MVRQ/MVRQ recipients (including three CD $18^{+}$-labeled $\mathrm{PBMC}$ recipients) became positive for $\mathrm{PrP}^{\mathrm{Sc}}$ labeling between 125 and $182 \mathrm{dpt}$ (Table 1 Figure 1C). There were no clinical signs of scrapie in any of these animals. All five were euthanized between 181 and $646 \mathrm{dpt}$. Rectal tissues, retropharyngeal lymph nodes and most other lymphoid tissues of all five animals showed positive $\mathrm{PrP}^{\mathrm{Sc}}$ labeling in lymphoid follicles (Tables 1 and 2). $\mathrm{PrP}^{\mathrm{Sc}}$ labeling in brain tissues was only detected in one animal (ID 4302). Antemortem rectal biopsies of six of nine MARQ/MVRQ 
Table 1 Sheep transfused with different blood components from scrapie infected sheep.

\begin{tabular}{|c|c|c|c|c|c|c|c|c|c|}
\hline \multicolumn{5}{|c|}{ Transfusion types } & \multicolumn{5}{|c|}{ Transfusion outcomes } \\
\hline $\begin{array}{l}\text { Blood } \\
\text { component }\end{array}$ & $\begin{array}{l}\text { blood volume } \\
(\mathrm{mL})^{1}\end{array}$ & $\begin{array}{l}\text { Donor } \\
\text { ID }\end{array}$ & $\begin{array}{l}\text { Clinical } \\
\text { status }\end{array}$ & $\begin{array}{l}\text { Donor } \\
\text { PRNP }\end{array}$ & $\begin{array}{l}\text { Recipient } \\
\text { PRNP }\end{array}$ & Recipient ID & $\begin{array}{l}\text { Rectal tissues PrP }{ }^{\text {Sc }} \text { detection by } \\
\text { IHC }\end{array}$ & $\begin{array}{l}\text { dpt to first positive } \\
\text { biopsy }\end{array}$ & $\begin{array}{l}\text { dpt at } \\
\text { necropsy }\end{array}$ \\
\hline \multirow[t]{7}{*}{ Whole blood } & 50 & $\begin{array}{l}3806 / \\
3807\end{array}$ & Preclinical & $\begin{array}{l}\text { MVRQ/ } \\
\text { MVRQ }\end{array}$ & MARQ/MVRQ & $\begin{array}{l}4128 / 4132 / \\
4134\end{array}$ & Positive & $156-235$ & 267 \\
\hline & 131 & 3178 & Preclinical & $\begin{array}{l}\text { MARQ/ } \\
\text { MARQ }\end{array}$ & MARQ/MARQ & 3668 & Positive & 252 & 261 \\
\hline & & & & & MARQ/TARQ & $3669 / 3670$ & Not detected & & 236-261 \\
\hline & 135 & 3187 & Clinical & $\begin{array}{l}\text { MARQ/ } \\
\text { MVRQ }\end{array}$ & TARQ/MVRQ & $3613 / 3622$ & Positive & & $185-213$ \\
\hline & & 3188 & Clinical & $\begin{array}{l}\text { MARQ/ } \\
\text { MVRQ }\end{array}$ & TARQ/MVRQ & 3628 & Not detected & & 213 \\
\hline & & & & & MARQ/MVRQ & 3672 & Positive & 123 & 215 \\
\hline & $119-131$ & 3199 & Clinical & $\begin{array}{l}\text { MARQ/ } \\
\text { MARQ }\end{array}$ & MARQ/MARQ & $\begin{array}{l}3665 / 3666 / \\
3667\end{array}$ & Positive & $222-252$ & $236-261$ \\
\hline \multirow[t]{4}{*}{ Buffy coat } & 100 & 3345 & Clinical & $\begin{array}{l}\text { MARQ/ } \\
\text { MARQ }\end{array}$ & MARQ/MARQ & $3823 / 3833$ & Positive & $239-288$ & 275-306 \\
\hline & & & & & MARQ/MARQ & 3832 & Positive & 549 & 1259 \\
\hline & & & & & MARQ/TARQ & 3819 & Positive & 757 & 1391 \\
\hline & & & & & MARQ/TARQ & 3825 & Not detected & & 1391 \\
\hline \multirow[t]{10}{*}{ PBMCs } & 50 & 4073 & Preclinical & $\begin{array}{l}\text { MVRQ/ } \\
\text { MVRQ }\end{array}$ & MVRQ/MVRQ & 4302 & Positive & 182 & 646 \\
\hline & & & & & MARQ/MVRQ & $4288 / 4309$ & Positive & 182 & 646 \\
\hline & & & & & MARQ/MVRQ & $4304 / 4305$ & Positive & & 251 \\
\hline & 100 & $\begin{array}{l}3806 / \\
3807\end{array}$ & Preclinical & $\begin{array}{l}\text { MVRQ/ } \\
\text { MVRQ }\end{array}$ & MARQ/MVRQ & $\begin{array}{l}4118 / 4119 / \\
4123\end{array}$ & Positive & 153-214 & 306 \\
\hline & & & & & TARQ/MVRQ & 4120 & Positive & 153 & 306 \\
\hline & 116 & 3774 & Preclinical & $\begin{array}{l}\text { MVRQ/ } \\
\text { MVRQ }\end{array}$ & MVRQ/MVRQ & 3824 & Positive & 175 & 183 \\
\hline & & & & & MARQ/MVRQ & 3921 & Positive & 175 & 183 \\
\hline & & & & & MARQ/MVRQ & 3920 & Positive & & 187 \\
\hline & $50^{@}$ & 4125 & Preclinical & $\begin{array}{l}\text { MVRQ/ } \\
\text { MVRQ }\end{array}$ & MVRQ/MVRQ & $4378 / 4380$ & Positive & 125 & 181 \\
\hline & & & & & MVRQ/MVRQ & 4379 & Positive & & 181 \\
\hline $\mathrm{CD}_{2}{ }^{+} \mathrm{B}$ cells & $50^{\#}$ & 4125 & Preclinical & $\begin{array}{l}\text { MVRQ/ } \\
\text { MVRQ }\end{array}$ & MVRQ/MVRQ & $\begin{array}{l}4384 / 4385 / \\
4386\end{array}$ & Positive & $125-152$ & 181 \\
\hline \multirow[t]{2}{*}{$\mathrm{CD}_{21}{ }^{+} \mathrm{B}$ cells } & $50^{2}$ & 4125 & Preclinical & $\begin{array}{l}\text { MVRQ/ } \\
\text { MVRQ }\end{array}$ & MVRQ/MVRQ & $4381 / 4383$ & Positive & $125-152$ & 187 \\
\hline & & & & & MVRQ/MVRQ & 4382 & Positive & & 187 \\
\hline
\end{tabular}


Table 1 Sheep transfused with different blood components from scrapie infected sheep. (Continued)

\begin{tabular}{|c|c|c|c|c|c|c|c|c|c|}
\hline Platelet-rich & 180 & 3199 & Clinical & $\begin{array}{l}\text { MARQ/ } \\
\text { MARQ }\end{array}$ & MARQ/MARQ & 3606 & Positive & 218 & 357 \\
\hline \multirow[t]{2}{*}{ plasma } & 100 & 3345 & Clinical & $\begin{array}{l}\text { MARQ/ } \\
\text { MARQ }\end{array}$ & MARQ/MARQ & 3820 & Positive & 288 & 554 \\
\hline & & & & & MARQ/MARQ & 3821 & Not detected & & 552 \\
\hline $\begin{array}{l}\text { Platelet-poor } \\
\text { plasma }\end{array}$ & 100 & 3345 & Clinical & $\begin{array}{l}\text { MARQ/ } \\
\text { MARQ }\end{array}$ & MARQ/MARQ & $\begin{array}{l}3822 / 3836 / \\
3838\end{array}$ & Not detected & & 549 \\
\hline
\end{tabular}

abbreviations: PBMCs = peripheral blood mononuclear cells; IHC = immunohistochemistry on antemortem and postmortem rectal tissues; PRNP = haplotypes shown include deduced amino acids at codons 112,136 154, 171; dpt = days post-transfusion; cells labeled with magnetic beads: ${ }^{\circledR} \mathrm{CD} 18$-labeled PBMCs; ${ }^{*} \mathrm{CD} 72$-labeled B cells (Pan B lymphocytes); ${ }^{\circledR} \mathrm{CD} 21$-labeled CD21 ${ }^{+} \mathrm{B}$ cells (a subpopulation of B lymphocytes), these

cells were labeled with primary and magnetic microbeads coupled secondary antibodies

${ }^{1}$ Total whole blood volume from which each inoculum was derived per recipient animal. 
Table 2 Summary of $\mathrm{PrP}^{\mathrm{Sc}}$ detection in multiple tissues from sheep transfused with different blood components from scrapie infected sheep

\begin{tabular}{|c|c|c|c|c|c|}
\hline \multirow[t]{3}{*}{ Blood components } & \multirow{3}{*}{$\begin{array}{c}\text { Recipient } \\
\text { PRNP }\end{array}$} & \multicolumn{3}{|c|}{$\mathrm{PrP}^{\mathrm{Sc}}$ detection by IHC } & \multirow{3}{*}{$\begin{array}{l}{ }^{*} \text { Scrapie } \\
\text { positive (\% }\end{array}$} \\
\hline & & \multirow{2}{*}{$\begin{array}{l}\text { Antemortem } \\
\text { Rectal tissues }\end{array}$} & \multicolumn{2}{|r|}{ Postmortem } & \\
\hline & & & $\begin{array}{l}\text { Rectal } \\
\text { tissues }\end{array}$ & Other lymphoid tissues & \\
\hline \multirow[t]{4}{*}{ Whole blood } & MARQ/MARQ & $4 / 4$ & $4 / 4$ & $4 / 4$ & 100 \\
\hline & MARQ/MVRQ & $3 / 4$ & $4 / 4$ & $4 / 4$ & 100 \\
\hline & MARQ/TARQ & $0 / 2$ & $0 / 2$ & $0 / 2$ & 0 \\
\hline & TARQ/MVRQ & $0 / 3$ & $2 / 3$ & $3 / 3$ & 100 \\
\hline \multirow[t]{2}{*}{ Buffy coat } & MARQ/MARQ & $3 / 3$ & $3 / 3$ & $3 / 3$ & 100 \\
\hline & MARQ/TARQ & $1 / 2$ & $1 / 2$ & $2 / 2$ & 100 \\
\hline \multirow[t]{3}{*}{ PBMCs } & MVRQ/MVRQ & $4 / 5$ & $5 / 5$ & $5 / 5$ & 100 \\
\hline & MARQ/MVRQ & $6 / 9$ & $7 / 9$ & $9 / 9$ & 100 \\
\hline & TARQ/MVRQ & $1 / 1$ & $1 / 1$ & $1 / 1$ & 100 \\
\hline $\mathrm{CD}_{2}{ }^{+} \mathrm{B}$ lymphocytes & MVRQ/MVRQ & $3 / 3$ & $3 / 3$ & $3 / 3$ & 100 \\
\hline CD21+ B lymphocytes & MVRQ/MVRQ & $2 / 3$ & $3 / 3$ & $3 / 3$ & 100 \\
\hline Platelet-rich plasma & MARQ/MARQ & $2 / 3$ & $2 / 3$ & $2 / 3$ & 67 \\
\hline Platelet-poor plasma & MARQ/MARQ & $0 / 3$ & $0 / 3$ & $0 / 3$ & 0 \\
\hline
\end{tabular}

Other lymphoid tissues = retropharyngeal lymph nodes, palatine tonsil, spleen, ileo-cecal junction, ileo-cecal lymph node or mesenteric lymph nodes; IHC = immunohistochemistry; *Scrapie positive PrP ${ }^{\mathrm{Sc}}$ was detected in one or more lymphoid tissues at necropsy

animals showed positive $\mathrm{PrP}^{\mathrm{Sc}}$ labeling in lymphoid follicles between 153 and $214 \mathrm{dpt}$. Rectal tissues collected at necropsy from two of three previously RAMALT PrP $\mathrm{P}^{\mathrm{Sc}}$ undetectable animals remained undetectable for $\operatorname{Pr} \mathrm{P}^{\mathrm{Sc}}$ labeling in lymphoid follicles (Table 2). Only the retropharyngeal lymph node of one recipient (ID 4305) showed positive $\mathrm{PrP}^{\mathrm{Sc}}$ labeling while most of the other lymphoid tissues collected at necropsy from all the other eight animals showed positive $\operatorname{PrP}^{\mathrm{Sc}}$ labeling in lymphoid follicles. Brain tissues of two animals necropsied at $646 \mathrm{dpt}$ showed positive $\operatorname{PrP}^{\mathrm{Sc}}$ labeling while $\operatorname{PrP}^{\mathrm{Sc}}$ labeling was not detected in all the other animals. Antemortem rectal tissue of the remaining TARQ/MVRQ recipient was positive for $\mathrm{PrP}^{\mathrm{Sc}}$ at $153 \mathrm{dpt}$. Rectal tissues, retropharyngeal lymph nodes and several other lymphoid tissues collected at necropsy from this animal showed positive $\mathrm{PrP}^{\mathrm{Sc}}$ labeling in lymphoid follicles (Table 2). However, $\operatorname{PrP}^{\mathrm{Sc}}$ was not undetected in the brain tissues.

\section{(iv) $B$ lymphocyte recipients develop preclinical scrapie}

Since PBMCs from four donor animals were able to cause scrapie in recipient sheep, another preclinical scrapie infected sheep was selected as a blood donor to identify prion infectivity in B lymphocytes. As a control for the study, three recipients were transfused with CD18-labeled PBMCs and all the recipients in this group showed positive $\operatorname{PrP}^{\mathrm{Sc}}$ labeling in lymphoid follicles (Table 1). Since MVRQ/MVRQ animals became $\operatorname{Pr} \mathrm{P}^{\mathrm{Sc}}$ positive more quickly than other genotypes, six lambs with this genotype were selected for the $\mathrm{B}$ lymphocyte transfusion experiment. CD $72^{+}$B lymphocytes and $\mathrm{CD} 21^{+}$B lymphocytes were separated from PBMCs using a magnetic labeling procedure with $95 \%$ purity as assessed by flow cytometry (data not shown). IHC examination of antemortem rectal biopsies collected from all three $\mathrm{CD}_{2} 2^{+}$(Figure 1D) and two of three $\mathrm{CD} 21^{+}$(Figure 1E) B lymphocyte recipients showed positive $\operatorname{PrP}^{\mathrm{Sc}}$ labeling between 125 and $152 \mathrm{dpt}$ (Table 1). Rectal as well as all the other lymphoid tissues collected from both types of B lymphocyte recipients at necropsy showed positive $\operatorname{PrP}^{\mathrm{Sc}}$ labeling in lymphoid follicles (Table 2). However, $\operatorname{PrP}^{\mathrm{Sc}}$ was not detected from any of the brain tissues of all six animals.

(v) Platelet-rich plasma recipients develop preclinical scrapie Platelet-rich and platelet-poor plasma was prepared from two clinical scrapie infected donor sheep and transfused to six recipients. Three MARQ/MARQ lambs were transfused with platelet-rich plasma prepared from two clinical scrapie donors (Table 1). Antemortem rectal biopsies of two of three recipients showed positive $\mathrm{PrP}^{\mathrm{Sc}}$ labeling between 218 and $288 \mathrm{dpt}$ (Figure 1F). The three animals did not show any clinical signs of scrapie when they were euthanized at 357 or $554 \mathrm{dpt}$. $\operatorname{PrP}^{\mathrm{Sc}}$ was detected in retropharyngeal lymph nodes and all the other lymphoid tissues examined in the two rectal biopsy positive animals, but $\operatorname{PrP}^{\mathrm{Sc}}$ was not detected in the same tissues in the previously biopsy negative animal (Table 2). In addition, $\operatorname{PrP}^{\mathrm{Sc}}$ remained undetectable in brain tissues from these animals. $\operatorname{PrP}^{S c}$ was not detected in the tissues from the three recipients of platelet-poor plasma when euthanized at $549 \mathrm{dpt}$ (Table 1 Table 2 Figure 1G). 


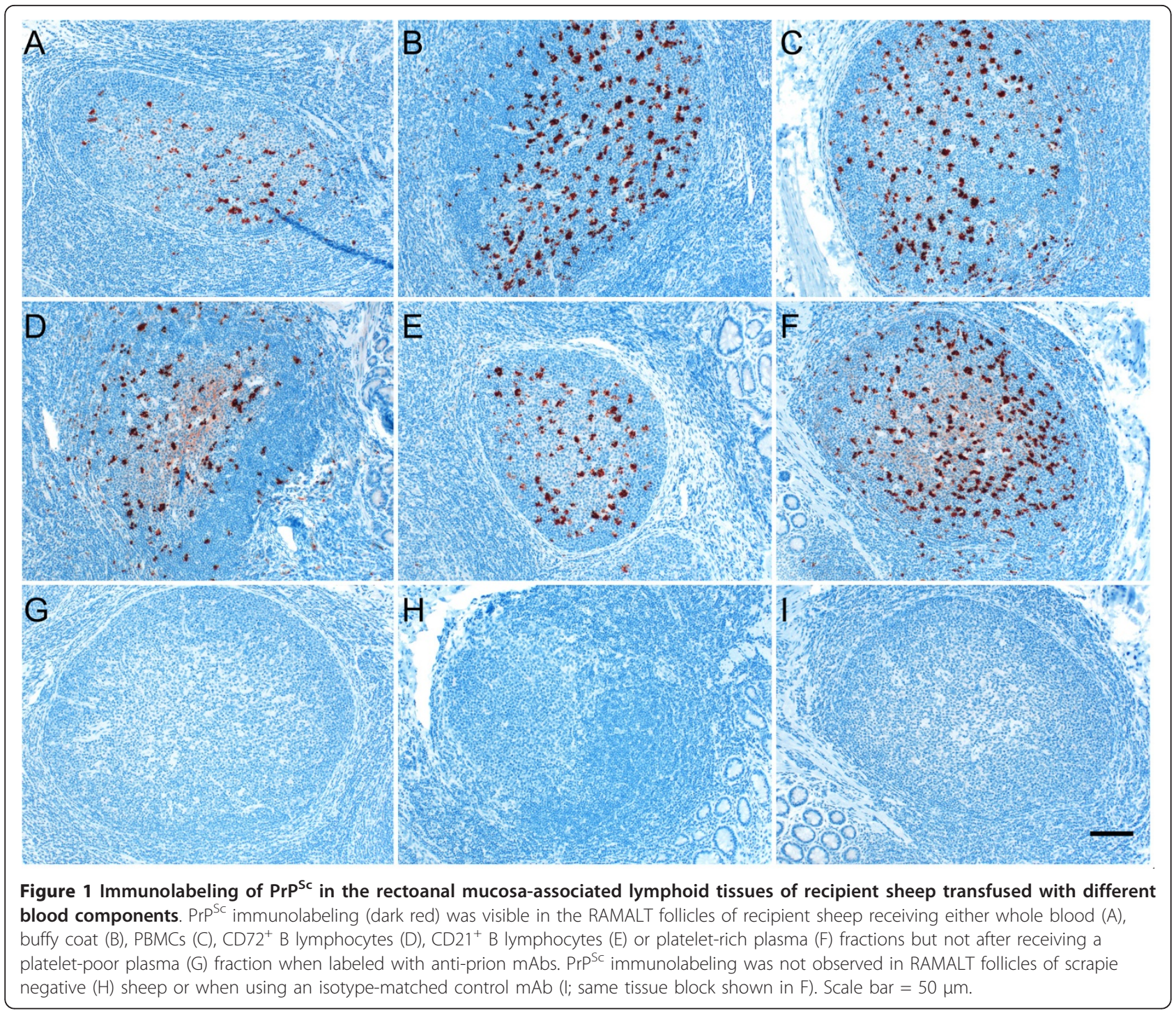

\section{Discussion}

Removal of exogenous and endogenous prion infectivity from red blood cell preparations of scrapie-infected hamster blood by leukoreduction filters resulted in significant reduction of scrapie infection in hamsters following transfusion [16]. Leukodepletion significantly reduced the risk of VCJD transmission in human following blood transfusion recipients as well $[17,18]$. However, a recent study by McCutcheon et al., (2011) revealed that leucoreduction did not prevent the BSE transmission to sheep following a single blood transfusion [11]. Detection of $\mathrm{PrP}^{\mathrm{Sc}}$ labeling in the lymphoid tissues and development of clinical scrapie in whole blood and buffy coat transfusion recipients in this study as well as in previous studies [8-10] confirmed that prion infectivity is associated with blood from classical scrapie infected sheep. Although previous sheep blood transfusion studies used a relatively large volume of whole blood (400 - $500 \mathrm{~mL}$ ), volumes of $50-135 \mathrm{~mL}$ whole blood from scrapie infected sheep were sufficient to transmit scrapie infection to the most recipients in this study. It is difficult to avoid the loss of PBMCs during density-gradient cell separation and MACS-based cell enrichment procedures $\left(\mathrm{CD} 72^{+}\right.$and/or $\mathrm{CD} 21^{+} \mathrm{B}$ lymphocytes) due to the multiple washing steps involved and the inherent limitation to the cell-binding capacity of the columns. Therefore, it is possible that even much lower volumes of scrapie infected sheep blood might be sufficient to cause infection in sheep. Demonstration of prion infectivity in much smaller volumes of blood may be helpful in development of conventional blood-based diagnostic testing for scrapie in sheep.

We used standard IHC detection of $\operatorname{PrP}^{\mathrm{Sc}}$ in tissues as a surrogate marker for transmission of infectivity to 
preclinical recipient sheep. Analysis of antemortem and postmortem lymphoid tissues in sheep receiving transfusion with the PBMC fractions were confirmed positive for $\mathrm{PrP}^{\mathrm{Sc}}$ immunolabeling indicating that prion infectivity is associated with PBMC fraction of sheep blood. Previous studies showed $\mathrm{PrP}^{\mathrm{Sc}}$ was detected from PBMCs $[12,13]$ and a subpopulation of B lymphocytes [14]. CD72 has been identified as a pan B lymphocyte marker in sheep [19] and also in mice [20]. Approximately 50\% of adult sheep B lymphocytes are positive for CD21 [19]. A significant proportion of peripheral lymphocytes recirculate continuously between the blood, the lymph and the tissues. The lymph nodes are the major site of exchange for recirculating lymphocytes between the blood and the lymph. The migration competent or recirculating B lymphocytes readily migrate into the lymphatic recirculation pathway due to the cell surface expression of CD21 and CD62L or L-selectin [19]. Therefore, we used anti-CD72 and anti-CD21 mAbs to isolate pan B lymphocytes and recirculating $\mathrm{B}$ lymphocytes from the PBMCs fraction, respectively. Transfusion of $\mathrm{CD}^{+} 2^{+} \mathrm{B}$ lymphocytes or CD $21^{+}$B lymphocytes from scrapie infected sheep resulted in $\mathrm{PrP}^{\mathrm{Sc}}$ detection in lymphoid tissues of recipients. These results are consistent with $\operatorname{PrP}^{\mathrm{Sc}}$ being detected in MHC class II DQ ${ }^{+}, \operatorname{sIgM}^{+}, \mathrm{CD}_{11 b^{+}}, \mathrm{CD}_{11 \mathrm{c}^{+}}$ and $\mathrm{CD} 21^{+/-} \mathrm{B}$ lymphocytes in sheep [14], and $\mathrm{CD}^{+} 2^{+} \mathrm{B}$ lymphocytes harboring infectious CWD prions in whitetailed deer [21].

The present study utilized a short observation period in the natural host as a model biased for quick detection of blood fractions having relatively high prion levels. The platelet-poor plasma fraction from scrapie infected sheep did not contain adequate levels of prion infectivity for detection in this model. Two of the three MARQ/MARQ lambs transfused with platelet rich plasma were positive by rectal biopsy 218 and 288 post-transfusion, approximately the same interval seen in MARQ/MARQ lambs transfused with whole blood (222-252 dpt, n = 4) or buffy coat cells (239-288 days, $n=2)$. CWD and BSE infectivity were associated with platelets or platelet-rich plasma pellets in white-tailed deer [21] and sheep [11], respectively. However, hamsters inoculated with platelets from scrapie infected hamsters did not develop scrapie [22]. The possibility exists that rodent models and ruminants have slightly different cells that contain infectivity or the processing of platelets could affect scrapie infectivity. Other studies have suggested that there is cell-free $\mathrm{PrP}^{\mathrm{Sc}}$ in sheep plasma $[15,22]$. Passage of radioactively labeled, highly purified murine $\operatorname{PrP}^{\mathrm{Sc}}$ through the mouse blood-brain barrier [23] and detection of $\operatorname{PrP}^{\mathrm{Sc}}$ in sheep circumventricular organs that lack a blood-brain barrier [24] suggest the possibility of cell-free $\mathrm{PrP}^{\mathrm{Sc}}$ in the blood. Detection of $\mathrm{PrP}^{\mathrm{Sc}}$ by PMCA in hamster plasma samples devoid of platelets suggests the possibility of cell-free
$\operatorname{PrP}^{\mathrm{Sc}}$ in hamster plasma [25,26]. Similarly, vCJD infectivity in plasma components has been reported from human donors suggesting cell-free plasma can also carry infectious vCJD prions $[27,28]$. Given the similarity in pathogenesis between BSE and scrapie infection in sheep, one would expect similar outcome from both forms. However, a recent study by McCutcheon et al., (2011) with BSE-infected sheep revealed that platelet-poor plasma supernatant can also efficiently transmit prion infectivity to recipient lambs following a single blood transfusion [11]. The detection of preclinical scrapie in recipient lambs took 594 to $1089 \mathrm{dpt}$. The lack of $\mathrm{PrP}^{\mathrm{Sc}}$ detection in lymphoid tissues of platelet-poor plasma recipients in our study could have been due to a lower prion titer in platelet-poor plasma samples and/or necropsy of animals at $550 \mathrm{dpt}$. Poisson distribution of particles in solution indicates a far greater number of recipient animals per group would have been necessary to distinguish sample fraction "titers". In contrast to sheep, hamster and human findings, recent studies in white-tailed deer and cervidized transgenic mouse revealed that CWD infectivity was not associated with platelet-poor plasma, but with platelets [21]. Although the presence of $\mathrm{PrP}^{\mathrm{Sc}}$ in hamsters' plasma fraction is confirmed, prion infectivity in that fraction has not yet been reported.

Our previous study demonstrated that one nonsynonymous allele (T112) was associated with prolonged survival in MARQ/TARQ scrapie-exposed sheep compared to MARQ/MARQ sheep [29]. Although the focus of this study was to identify which blood components carry prion infectivity, four MARQ/TARQ and four TARQ/ MVRQ animals were included to assess whether T112 polymorphism might delay $\mathrm{PrP}^{\mathrm{Sc}}$ detection in RAMALT follicles following infection by transfusion. Lack of $\mathrm{PrP}^{\mathrm{Sc}}$ labeling in RAMALT follicles of six of eight recipients confirms that T112 polymorphism delayed prion accumulation in sheep rectal lymphoid tissues. Although the number of animals used in this study was limited, the delay in $\operatorname{PrP}^{\mathrm{Sc}}$ accumulation in RAMALT particularly in MARQ/TARQ animals needs to be considered when scrapie diagnosis is determined.

\section{Conclusions}

This study demonstrated that prion infectivity is associated with B lymphocytes and platelet-rich plasma of sheep with classical scrapie. Enrichment of platelets as well as B lymphocytes should enhance assay detection sensitivity for scrapie.

\section{Methods}

\section{Blood donor and recipient sheep}

All experimental protocols used in this study were approved by the Institutional Animal Care and Use Committee (IACUC) at Washington State University before 
onset of the study. All donor animals were naturally infected with scrapie and housed at a USDA ARS quarantine facility. Six preclinical (1 MARQ/MARQ, 5 MVRQ/ MVRQ) and four clinical (2 MARQ/MARQ, 2 MARQ/ MVRQ) scrapie animals were selected as blood donors. Eight of the donor sheep were born and raised in a persistently scrapie-infected flock at the USDA animal research unit at Pullman, WA and developed either preclinical or clinical scrapie. Donor 3774 was received from a privately owned scrapie-infected flock while 4125 was brought from a clean flock and developed preclinical scrapie at our research facility. These animals were mixed breeds of white face or black face sheep. The ages of the donor animals were in the range of 14 to 36 months at the time of blood collection. $\operatorname{PrP}^{\mathrm{Sc}}$ was detected by IHC in brain and lymphoid tissues collected at necropsy from all the donor sheep (Figure 2). To further confirm $\operatorname{PrP}^{\mathrm{Sc}}$ detection by IHC, two preclinical and four clinical donor brain tissues were selected for western blot study. Three PK-resistant bands corresponding to di-, mono- and un-glycosylated isoforms of $\mathrm{PrP}^{\mathrm{Sc}}$ were detected with anti-prion mAb F99/97.6.1 [5] (data not shown). Serum samples collected from donor and recipient animals were negative for ovine progressive pneumonia virus antibody using a cELISA (data not shown). The PRNP genotypes of donor and recipient sheep were determined by sequencing of open reading frame of the PRNP gene [30]. Genotypes are shown by the deduced amino acid residues at positions 112, 136, 154 and 171 respectively. Sheep with PRNP genotypes encoding methionine $(\mathrm{M})$ or threonine $(\mathrm{T})$ at codon 112, alanine (A) or valine $(\mathrm{V})$ at 136 , arginine $(\mathrm{R})$ at 154 and glutamine $(\mathrm{Q})$ at 171 were selected for this study. PRNP genotypes and scrapie status of donor and recipient sheep are shown in Table 1. At approximately fourmonths of age, recipient lambs received from a scrapie negative flock at our facility, USDA ARS sheep experiment station at Dubois, ID, University of Idaho, Moscow, ID or privately owned farms were transferred to isolation buildings or outdoor pens with no direct contact with scrapie infected sheep. These lambs were mixed breed of white face or black face sheep.

\section{Isolation of blood components and transfusion}

All the donor animals were physically restrained during the blood collection and no chemical sedatives were used. During blood transfusion, lambs were also physically restrained and blood or blood components were administered through jugular vein. Jugular venous blood samples from six preclinical and four clinical scrapie positive donor sheep were collected into evacuated containers (Baxter Healthcare Co., Deerfield, IL; 150 - 500 mL capacity) containing acid citrate dextrose as an anticoagulant. The volume of whole blood and the blood fractions derived

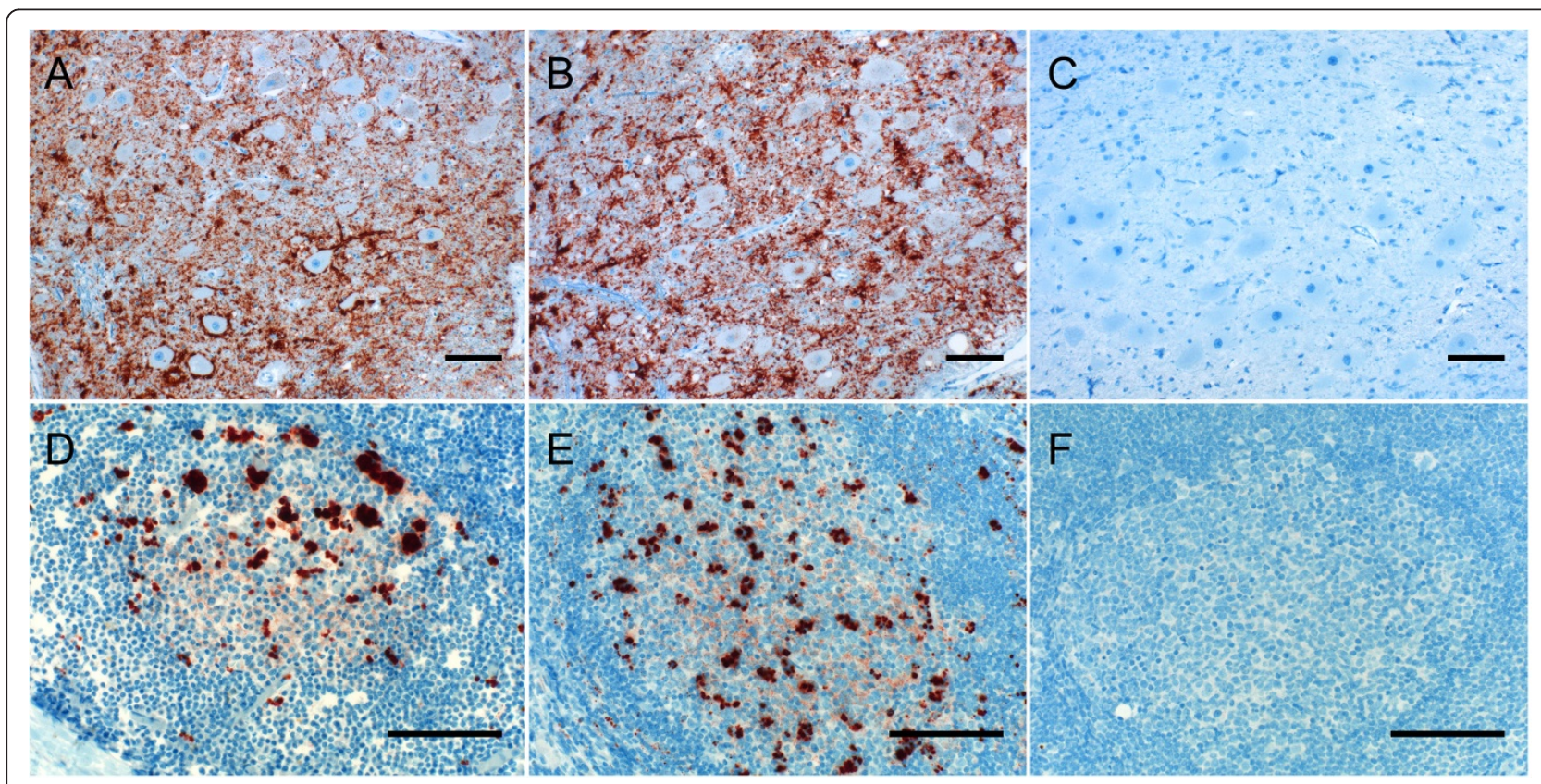

Figure 2 Immunolabeling of $\mathrm{PrP}^{\mathrm{Sc}}$ in the brains and retropharyngeal lymph nodes of scrapie infected donor sheep. Widespread immunolabeling of $\operatorname{PrP}^{S C}$ (dark red) deposits was observed in the brains (A, B) and retropharyngeal lymph node follicles (D, E) of preclinical and clinical scrapie infected donor animals after labeling tissues with anti-prion mAbs, respectively. No PrPSc immunolabeling was observed in the brain from a sheep without scrapie labeled with the same anti-prion mAbs (C). Immunolabeling of retropharyngeal lymph nodes section from the same scrapie donor sheep (E) block labeled with isotype-matched control mAb (F) shows no non-specific labeling. Scale bars $=50 \mu m$. 
from the starting volume of donor blood used for transfusion are shown in Table 1. Each animal received the indicated volume of blood or the cells isolated from the indicated volume of whole blood. Plasma from whole blood was initially separated by centrifugation $(380 \times \mathrm{g}$ for $30 \mathrm{~min})$ and was further centrifuged $(1500 \times \mathrm{g}$ twice for $15 \mathrm{~min}$ each) to prepare platelet-poor plasma. Buffy coat cells collected from centrifuged blood samples were washed twice with phosphate-buffered saline (PBS, Cellgro Inc., Manassas, VA) containing 2 mM EDTA (PBS-EDTA, $\mathrm{pH}$ 7.2). Erythrocytes were removed by a short incubation of the buffy coat in erythrocyte lysis solution (Qiagen Inc., Valence, CA) followed by two washes in PBS-EDTA. Thereafter, each buffy coat pellet was re-suspended in 10 $\mathrm{mL}$ normal saline and transfused into recipient lambs through the jugular vein. To separate peripheral blood mononuclear cells (PBMCs) from polymorphonuclear cells, buffy coat suspensions were carefully layered onto Accu-Paque ${ }^{\mathrm{TM}}$ (Accurate Chemicals, Westbury, NY) density gradient solution (density - $1.088 \mathrm{~g} / \mathrm{mL}$; osmolarity $350 \mathrm{mOsm}$ ) and centrifuged $(380 \times \mathrm{g}$ for $30 \mathrm{~min})$. PBMCs were collected from the plasma-Accu-Paque interface and any remaining erythrocytes were removed by incubation with erythrocyte lysis solution. PBMCs were washed twice with PBS-EDTA, resuspended in $10 \mathrm{~mL}$ normal saline and transfused into recipient lambs

PBMCs collected from $450 \mathrm{~mL}$ of blood from donor sheep 4125 (Table 1) were further processed to enrich for B lymphocytes using a magnetic cell sorting system (MACS; Miltenyi Biotech, Auburn, CA). Briefly, PBMCs were resuspended in Hanks-balanced salt solution (HBSS; Invitrogen, Carlsbad, CA) containing $2 \mathrm{mM}$ EDTA and $2 \%$ fetal bovine serum (FBS) and divided into three tubes. Each tube was then incubated with either anti-CD72 (2104, IgM, kindly provided by Dr. Young), anti-CD21 (BAQ15A, IgM; VMRD Inc., Pullman WA) or anti-CD18 (HUH82A, IgG2a; VMRD) murine monoclonal antibodies (mAbs) for $30 \mathrm{~min}$ on ice. Cells in each tube were washed twice in HBSS and then incubated with rat anti-mouse IgM- or IgG2a-b- coupled magnetic microbeads (Miltenyi) for $15 \mathrm{~min}$ on ice. To determine the enrichment purity by flow cytometry, mAb-labeled cells were incubated with either FITC-labeled goat anti-mouse IgM or IgG2a for 5 min. $\mathrm{CD}^{+} 2^{+}$and $\mathrm{CD} 21^{+}$labeled B lymphocytes were separated from other PBMCs by passing through LS MACS columns (Miltenyi), washed, and resuspended in $10 \mathrm{~mL}$ normal saline. To assess whether magnetic labeling of cells interferes with cell circulation and prion development, PBMCs were labeled with anti-CD18, anti-IgG2a-b and FITC-IgG2a mAbs. These CD18-labeled PBMCs were not subjected to MACS columns enrichment and were used as a positive control for the study. Approximately $5 \times$ $10^{7}$ CD18-labeled PBMCs, $2 \times 10^{7} \mathrm{CD}^{+} 2^{+} \mathrm{B}$ cells and $7 \times$ $10^{6} \mathrm{CD} 21^{+} \mathrm{B}$ cells were isolated from the initial $50 \mathrm{~mL}$ of whole blood and transfused into lambs. Lambs (three animals per group) received $\mathrm{CD} 72^{+} \mathrm{B}$ cells, $\mathrm{CD} 21^{+} \mathrm{B}$ cells or CD18-labeled PBMCs. Whole blood, platelet and plasma recipients were held in the quarantine facility in pens with no access to other infected sheep or goats.

\section{Scrapie diagnosis by immunohistochemistry and western blot assays}

Antemortem diagnosis of scrapie was made by biopsy of the rectal mucosa and detection of $\operatorname{PrP}^{\mathrm{Sc}}$ by IHC. Samples were collected from each recipient lamb as follows: MVRQ/MVRQ recipients: first biopsy at four months and monthly thereafter; MARQ/MVRQ or TARQ/MVRQ recipients: first biopsy at six months and one to two months thereafter; MARQ/MARQ or MARQ/TARQ recipients: first biopsy at eight months and nine, 15, 18, 25 and 36 months thereafter. Animals were euthanized by intravenous administration of a pentobarbital-based euthanasia solution (Vortech, Dearborn, MI) when most of the recipients in the same group became rectal biopsy positive for $\mathrm{PrP}^{\mathrm{Sc}}$ (Table 1). Antemortem and postmortem rectal tissues, postmortem lymphoid tissues (retropharyngeal lymph nodes, palatine tonsils, spleen, ileo-cecal junction, ileo-cecal lymph nodes and mesenteric lymph nodes) and brains were fixed in formalin and processed according to standard procedures. Three $\mu \mathrm{m}$ sections mounted on treated glass slides (Superfrost ${ }^{\circledR} /$ Plus, Fisher Scientific, Pittsburg, PA) were immunolabeled with a combination of mAbs F89/160.1.5 [31] and F99/97.6.1 [5] using an automated immunolabeler (Benchmark, Ventana Medical Systems, Tucson, AZ), and counterstained with hematoxylin as previously described [32]. Positive and negative ovine lymphoid and brain tissues were used as run control samples. Immunolabeling intensity of the positive control tissue was equivalent for all runs and no labeling was observed in negative control tissues or in positive control tissues for which an isotype-matched mAb was substituted for the anti-PrP mAbs. Samples were considered positive for $\mathrm{PrP}^{\mathrm{Sc}}$ if coarse dark red deposits were detected in the lymphoid follicles or in the dorsal motor nucleus of the vagus nerve at the level of obex by using bright-field microscopy. Photomicrographs were taken with an Olympus BX40 microscope coupled with an Olympus Q-Color3 camera. Axiovision software was used for scaling and Adobe Photoshop Elements 5.0 for formatting. Brain tissue samples from two preclinical and all four clinical donor sheep collected at necropsy were selected for further analysis for $\mathrm{PrP}^{\mathrm{Sc}}$ by western blot assays as described previously [32-34]. Briefly, proteinase $\mathrm{K}(50 \mu \mathrm{g} /$ $\mathrm{mL}$ final concentration) was directly added into $100 \mu \mathrm{l}$ $10 \%(\mathrm{w} / \mathrm{v})$ brain homogenates and incubated at $50^{\circ} \mathrm{C}$ for 1 h. Ten microliters of homogenates were mixed with SDSPAGE sample loading buffer and loaded onto a $12 \% \mathrm{Nu}$ PAGE Bis-Tris gel (Invitrogen). After electrophoresis, 
proteins were transferred onto PVDF membranes, blocked with commercial casein blocker (Pierce, Rockford, IL) and incubated with primary mAb F99/97.6.1 followed by incubation with a horseradish peroxidase conjugated goat antimouse secondary Ab (SouthernBiotech, Birmingham, AL). Bound antibody was detected by chemiluminescence (Amersham ECL ${ }^{\mathrm{TM}}$, GE healthcare, Piscataway, NJ). Membranes were exposed to radiographic films (KodakBioMax Chemiluminescence Films) and evaluated for di-, monoand un-glycosylated $\mathrm{PrP}^{\mathrm{Sc}}$ banding patterns. Positive and negative sheep brain homogenates and isotype-matched mAbs were used as controls for the assay.

\section{Acknowledgements \\ This research was support by the funds from the USDA Agricultural Research Service under CRIS 5348-32000-026-00 D. We thank Drs. D.P. Knowles and L. (Herrmann) Hoesing (USDA, Pullman, WA) for reading the manuscript and providing helpful comments, L. Hamburg for her support during blood transfusion experiments, and D. Lesiak for PRNP genotyping of both donor and recipient sheep. We also thank L. Fuller, D. Chandler and J. Luft for care of the animals and Washington Animal Disease Diagnostic Laboratory personnel at the histology laboratory for use of their tissue processor. Mention of trade names or commercial products in this article is solely for the purpose of providing specific information and does not imply recommendation or endorsement by the US Department of Agriculture.}

\section{Author details}

'Department of Veterinary Microbiology and Pathology, College of Veterinary Medicine, Washington State University, Pullman, WA 99164-7040 USA. ${ }^{2}$ Animal Disease Research Unit, Agricultural Research Service, U.S. Department of Agriculture, Pullman, WA 99164-6630 USA. ${ }^{3}$ Department of Veterinary and Biomedical Science, South Dakota State University, Brookings, SD 57007, USA.

\section{Authors' contributions}

$\mathrm{KO}$ and $\mathrm{RD}$ designed the experiments and analyzed the experimental data. $\mathrm{RD}$ prepared the manuscript. KO supervised the experiments and helped draft manuscript. DS performed the post mortem analysis and helped draft the manuscript. AY provide anti-CD72 mAb and helped draft manuscript. TT prepared the tissues, developed sections for immunolabeling and performed all the immunohistochemistry assays. DZ performed the western blot assays. All authors have read and approved the final manuscript.

Received: 8 July 2011 Accepted: 23 November 2011 Published: 23 November 2011

\section{References}

1. Bolton DC, McKinley MP, Prusiner SB: Identification of a protein that purifies with the scrapie prion. Science 1982, 218(4579):1309-1311.

2. Prusiner SB: Novel proteinaceous infectious particles cause scrapie. Science 1982, 216(4542):136-144.

3. van Keulen LJ, Schreuder BE, Meloen RH, Mooij-Harkes G, Vromans ME, Langeveld JP: Immunohistochemical detection of prion protein in lymphoid tissues of sheep with natural scrapie. J Clin Microbiol 1996, 34(5):1228-1231.

4. O'Rourke Kl, Baszler TV, Parish SM, Knowles DP: Preclinical detection of PrPSc in nictitating membrane lymphoid tissue of sheep. Vet Rec 1998, 142(18):489-491.

5. O'Rourke KI, Baszler TV, Besser TE, Miller JM, Cutlip RC, Wells GA, Ryder SJ, Parish SM, Hamir AN, Cockett NE, et al: Preclinical diagnosis of scrapie by immunohistochemistry of third eyelid lymphoid tissue. J Clin Microbiol 2000, 38(9):3254-3259.

6. Gonzalez L, Jeffrey M, Siso S, Martin S, Bellworthy SJ, Stack MJ, Chaplin MJ, Davis $L$, Dagleish MP, Reid HW: Diagnosis of preclinical scrapie in samples of rectal mucosa. Vet Rec 2005, 156(26):846-847.
7. Espenes A, Press CM, Landsverk T, Tranulis MA, Aleksandersen M, Gunnes $G$, Benestad SL, Fuglestveit R, Ulvund MJ: Detection of $\operatorname{PrP}(\mathrm{Sc})$ in rectal biopsy and necropsy samples from sheep with experimental scrapie. J Comp Pathol 2006, 134(2-3):115-125.

8. Houston F, Foster JD, Chong A, Hunter N, Bostock CJ: Transmission of BSE by blood transfusion in sheep. Lancet 2000, 356(9234):999-1000.

9. Houston F, McCutcheon S, Goldmann W, Chong A, Foster J, Siso S, Gonzalez L, Jeffrey M, Hunter N: Prion diseases are efficiently transmitted by blood transfusion in sheep. Blood 2008, 112(12):4739-4745.

10. Hunter N, Foster J, Chong A, McCutcheon S, Parnham D, Eaton S, Mackenzie C, Houston F: Transmission of prion diseases by blood transfusion. J Gen Virol 2002, 83(Pt 11):2897-2905.

11. McCutcheon S, Alejo Blanco AR, Houston EF, de Wolf C, Tan BC, Smith A, Groschup MH, Hunter N, Hornsey VS, MacGregor IR, et al: All clinicallyrelevant blood components transmit prion disease following a single blood transfusion: a sheep model of vCJD. PLoS One 2011, 6(8):e23169.

12. Thorne $L$, Terry LA: In vitro amplification of PrPSc derived from the brain and blood of sheep infected with scrapie. J Gen Virol 2008, 89(Pt 12):3177-3184.

13. Terry LA, Howells L, Hawthorn J, Edwards JC, Moore SJ, Bellworthy SJ, Simmons H, Lizano S, Estey L, Leathers V, et al: Detection of PrPsc in blood from sheep infected with the scrapie and bovine spongiform encephalopathy agents. J Virol 2009, 83(23):12552-12558.

14. Edwards JC, Moore SJ, Hawthorn JA, Neale MH, Terry LA: $\operatorname{PrP}(\mathrm{Sc})$ is associated with $B$ cells in the blood of scrapie-infected sheep. Virology 2010, 405(1):110-119.

15. Rubenstein R, Chang B, Gray P, Piltch M, Bulgin MS, Sorensen-Melson S, Miller MW: A novel method for preclinical detection of PrPSC in blood. $J$ Gen Virol 2010, 91(Pt 7):1883-1892.

16. Sowemimo-Coker S, Kascsak R, Kim A, Andrade F, Pesci S, Meeker C, Carp R, Brown P: Removal of exogenous (spiked) and endogenous prion infectivity from red cells with a new prototype of leukoreduction filter. Transfusion 2005, 45(12):1839-1844.

17. Cervia JS, Sowemimo-Coker SO, Ortolano GA, Wilkins K, Schaffer J, Wortham ST: An overview of prion biology and the role of blood filtration in reducing the risk of transfusion-transmitted variant Creutzfeldt-Jakob disease. Transfus Med Rev 2006, 20(3):190-206.

18. Hewitt PE, Llewelyn CA, Mackenzie J, Will RG: Creutzfeldt-Jakob disease and blood transfusion: results of the UK Transfusion Medicine Epidemiological Review study. Vox Sang 2006, 91(3):221-230

19. Young AJ, Dudler L, Yamaguchi K, Marston W, Hein WR: Structure and expression of ovine complement receptor type 2. Vet Immunol Immunopathol 1999, 72(1-2):67-72.

20. Pan C, Baumgarth N, Parnes JR: CD72-deficient mice reveal nonredundant roles of CD72 in B cell development and activation. Immunity 1999, 11(4):495-506

21. Mathiason CK, Hayes-Klug J, Hays SA, Powers J, Osborn DA, Dahmes SJ, Miller KV, Warren RJ, Mason GL, Telling GC, et al: B cells and platelets harbor prion infectivity in the blood of deer infected with chronic wasting disease. J Virol 2010, 84(10):5097-5107.

22. Holada K, Vostal JG, Theisen PW, MacAuley C, Gregori L, Rohwer RG: Scrapie infectivity in hamster blood is not associated with platelets. Virol 2002, 76(9):4649-4650.

23. Banks WA, Niehoff ML, Adessi C, Soto C: Passage of murine scrapie prion protein across the mouse vascular blood-brain barrier. Biochem Biophys Res Commun 2004, 318(1):125-130.

24. Siso $\mathrm{S}$, Jeffrey $\mathrm{M}$, Gonzalez L: Neuroinvasion in sheep transmissible spongiform encephalopathies: the role of the haematogenous route. Neuropathol Appl Neurobiol 2009, 35(3):232-246.

25. Murayama Y, Yoshioka M, Okada H, Takata M, Yokoyama T, Mohri S: Urinary excretion and blood level of prions in scrapie-infected hamsters. J Gen Virol 2007, 88(Pt 10):2890-2898.

26. Tsukui K, Takata M, Tadokoro K: A potential blood test for transmissible spongiform encephalopathies by detecting carbohydrate-dependent aggregates of PrPres-like proteins in scrapie-Infected hamster plasma. Microbiol Immunol 2007, 51(12):1221-1231.

27. Hewitt P: VCJD and blood transfusion in the United Kingdom. Transfus Clin Biol 2006, 13(5):312-316.

28. Lefrere JJ, Hewitt P: From mad cows to sensible blood transfusion: the risk of prion transmission by labile blood components in the United Kingdom and in France. Transfusion 2009, 49(4):797-812. 
29. Laegreid WW, Clawson ML, Heaton MP, Green BT, O'Rourke Kl, Knowles DP: Scrapie resistance in ARQ sheep. J Virol 2008, 82(20):10318-10320.

30. Baylis M, Goldmann W, Houston F, Cairns D, Chong A, Ross A, Smith A, Hunter N, McLean AR: Scrapie epidemic in a fully PrP-genotyped sheep flock. J Gen Virol 2002, 83(Pt 11):2907-2914.

31. O'Rourke Kl, Baszler TV, Miller JM, Spraker TR, Sadler-Riggleman I, Knowles DP: Monoclonal antibody F89/160.1.5 defines a conserved epitope on the ruminant prion protein. J Clin Microbiol 1998, 36(6):1750-1755.

32. O'Rourke Kl, Zhuang D, Truscott TC, Yan H, Schneider DA: Sparse PrP(Sc) accumulation in the placentas of goats with naturally acquired scrapie. BMC Vet Res 2011, 7:7.

33. Spraker TR, Balachandran A, Zhuang D, O'Rourke Kl: Variable patterns of distribution of $\operatorname{PrP}(C W D)$ in the obex and cranial lymphoid tissues of Rocky Mountain elk (Cervus elaphus nelsoni) with subclinical chronic wasting disease. Vet Rec 2004, 155(10):295-302.

34. Alverson J, O'Rourke Kl, Baszler TV: PrPSC accumulation in fetal cotyledons of scrapie-resistant lambs is influenced by fetus location in the uterus. J Gen Virol 2006, 87(Pt 4):1035-1041.

doi:10.1186/1746-6148-7-75

Cite this article as: Dassanayake et al: Classical scrapie prions in ovine blood are associated with B lymphocytes and platelet-rich plasma. BMC Veterinary Research 2011 7:75

\section{Submit your next manuscript to BioMed Central} and take full advantage of:

- Convenient online submission

- Thorough peer review

- No space constraints or color figure charges

- Immediate publication on acceptance

- Inclusion in PubMed, CAS, Scopus and Google Scholar

- Research which is freely available for redistribution

Submit your manuscript at www.biomedcentral.com/submit 